\title{
THE IMPLEMENTATION OF CHSE PROGRAM IN COURTYARD HOTEL BY MARRIOTT BALI NUSA DUA RESORT IN POST-COVID-19 PANDEMIC
}

\author{
I Wayan Kiki Sanjaya1, Ni Putu Sartika Sari2 \\ International Business and Tourism Institute \\ tikasartika@gmail.com¹, kikisanjayabali@gmail.com²
}

\begin{abstract}
This study is examining the implementation of CHSE program at Courtyard Hotel by Marriott Bali Nusa Dua Resort. CHSE certification program is issued by the Ministry of Tourism and Creative Economy, aimed to guarantee hygiene, health, safety and environmental sustainability for the products and services provided to tourists. This study is aimed at determining to what extend the Courtyard Hotel by Marriott Bali Nusa Dua Resort implemented CHSE protocol. This study was conducted using descriptive quantitative method with data collection techniques through observation and interviews as well as literature study. The findings were then analyzed using the theory of negotiation. The result indicated that the implementation of the CHSE protocols in training was successful. However, some improvements are still needed concerning the employee discipline, the hotel management's readiness, and the standard operating procedure (SOP); as an attempt to convince potential tourists to visit and to stay at the hotel.
\end{abstract}

Keywords: Tourism, Covid-19 pandemic, CHSE, Hotel

\section{INTRODUCTION}

Indonesia and Bali specifically have been heavily hit by the Corona virus (Covid-19) pandemic. Tourism which is the backbone of its economy is the most directly affected sector in this current crisis. Since the announcement of its first outbreak in Indonesia on March 3, 2020, tourism sector felt the negative impact of the crisis. According to online portal (cnbcindonesia.com, 2020), the economic growth in Bali was minus 9.31\% year-on-year (yoy). The first quarter of 2021 was still minus $5.15 \%$. The total loss caused by the pandemic reported by tempo.com (2021) has reached Rp. 85.7 trillion; impacted tour operators by 4 trillion, airlines by 11.7 trillion, hotels by 30 trillion, and restaurants by 40 trillion.

The government especially the Minister of Tourism and Creative Economy continues to make efforts in restoring the economy and in supporting tourism activities in Bali. Several agendas have been proclaimed, namely: "Program Bali 
kemBali", "work from Bali", CHSE program (Cleanliness, Health, Safety and Environment Sustainability). However, these programs have not been fully realized when Bali was categorized as red zone route and was at level four in mid-2021, in July to be precise. For the record, only CHSE program was underway because it was commenced in mid-2020 and has almost been realized.

CHSE program focuses on certification activities in the tourism system, including accommodations, attractions, and other sectors to ensure and to guarantee the safety of tourists during their visit. In addition to the general goals of revitalizing Indonesia's tourism sector and restoring the national economy, this program also has a specific objective, that is to certify accommodations which are ready, and worthy used as the country's pilot project for healthy tourism in the post Covid-19 outbreak. As quoted from Minister of Tourism and Creative Economy (2021), to get CHSE certification, hoteliers and tourism objects must go through four stages. First, in the aspect of cleanliness, business actors are required to ensure cleanliness in their place of business, to provide hand soap or hand sanitizer for visitors and to spray disinfectants as well. Second, in terms of maintaining health in the business area, business actors need to maintain the health of both workers and visitors by checking body temperature, wearing masks, implementing social restrictions by setting distance and minimizing crowds. Third, maintaining security and safety, where business actors are required to prepare rescue procedures in the event of a disaster or in an emergency. The aim is to ensure the safety of everyone, both visitors and employees in the area. Fourth, paying attention to environmental sustainability, business actors need to ensure that they have implemented environmentally friendly business, such as using eco-friendly equipment and materials.

Courtyard Hotel by Marriott Bali Nusa Dua Resort has successfully received CHSE certificates. There are at least two reasons to do research on this hotel. The first reason, this hotel is in the Nusa Dua area, which is an elite tourism area on the coastal side in south part of Bali. The second reason, in terms of land area, shape of the building, and number of employees in the early stage of data collection (on February 2021), it is assumed that this hotel will find it very difficult to implement the CHSE program.

The urgency of this research lies in how the implementation of CHSE program in the post-COVID-19 pandemic phase, especially at the Courtyard Hotel by Marriott Bali Nusa Dua Resort in Bali. The fear that this program will only be used as a symbol or a marketing gimmick to gain profits and only to support government programs is a challenge that must be answered. Another thing, there is not much writing about how the implementation of the CHSE program is the basis of this research. It is increasingly interesting to study through the formulation of the problem, namely how is the implementation of CHSE at the Courtyard Hotel by Marriott Bali Nusa Dua Resort in the post-covid-19 pandemic phase?

\section{Literature review}

References used in this paper are referred to and clustered according to the criteria. An implementation guidebook of CHSE was used as reference. It consists of health protocol in four areas, namely, Cleanliness, Health, Safety, and Environment Sustainability which was accessed from government website 
(accessed in August 2021 from kemenparekraf.go.id.). The list of guidebooks made has been adapted to the implementation of tourism activities in their respective fields. The hotel itself has two guidelines consisting of general guideline and specific guideline which are aimed at employers/hotel managers, guests, and employees. The general guideline contains governance guidelines in four areas of CHSE which are reviewed from the management aspect, while the specific guideline consists of procedures (SOP) of CHSE rules which is addressed to employees. Another criterion used in this paper is the standard of hygiene and sanitation at the Courtyard Hotel by Marriott Bali Nusa Dua Resort.

In analyzing the data, the theory of cultural study was used, namely the negotiation theory by Daniel Druckman (1997). This theory emphasis the meaning of negotiation that underlies structured actions (practices) at the Courtyard Hotel by Marriott Bali Nusa Dua Resort. This theory is also expected to provide form, function, and meaning for the application of CHSE at the Courtyard by Marriott Bali Nusa Dua Resort Hotel.

\section{METHODOLOGY}

This study used a qualitative descriptive analysis method. An observation, in-depth interviews and documentation or a triangulation were conducted in obtaining a valid and reliable data. At the initial stage, the researcher conducted a general exploration of the social situation/object being studied, everything seen and heard were recorded. The data reduction process is carried out by summarizing, selecting the key point, focusing on the important things, looking for themes, and discarding the unnecessary. Thus, the reduced data will provide a clearer picture, and makes it easier for researcher to conduct further data collection and look for it when needed. Furthermore, the presentation of the data and theories referred to in this study can be done in the form of a brief description and in a comprehensible language. Data analysis can be divided into data collection, data reduction, data presentation and drawing conclusions.

\section{RESULTS AND DISCUSSION}

\section{Hotel History and Facilities}

Marriott International, Inc. is a company operating in the hospitality sector, which was first founded on May 20, 1927, by John Willard Marriott, Sr., and his wife Alice Sheet, who initially opened a tavern. Next J. Willard Marriott and his wife Alice Sheets Marriott expanded by opening a restaurant. In 1957, John Willard Marriott, Sr., opened the first hotel, the Twin Bridges Marriott Motor Hotel, located in Arlington, Virginia, United States. Then the opening of a second hotel, Key Bridge Marriott, in the same place. J.W. (Bill) Marriott, Jr. then continued his family-owned hospitality business which is growing rapidly in the world. Currently, Marriot International manages more than 710 properties in 23 countries and one of the properties is Courtyard, where there are only three Courtyard properties in Indonesia that have been registered, they are in Nusa Dua (Bali), Seminyak (Bali), and in Bandung (West Java). The focus of this research is Courtyard Hotel Nusa Dua, which formerly was the location of Hotel Club Bualu. In 2005, it was taken over by PT. Peninsula Bali Resort, then in 2006, it was rebuilt by Marriott 
International. Almost four years, at the end of 2010 to be precise, the construction had reached 75\%. So that on February 4, 2011, Hotel Courtyard by Marriott Bali Nusa Dua Resort was opened and is operating up to the present time.

In terms of facilities, Courtyard Hotel by Marriott Bali Nusa Dua Resort has extensive accommodation facilities. The results of documentation and observational study found that the hotel has 300 guest rooms. The guest rooms consist of several types of rooms, such as: Deluxe Garden View, Deluxe Pool View, Premium Deluxe, Deluxe Pool Terrace, and Suite with a private balcony and views to the garden or pool as well as direct access to the swimming pool. Concerning food and beverage services, Courtyard Hotel by Marriott Bali Nusa Dua Resort indulges its guests with all day dining restaurant and daily buffet breakfast that operate from $06.00 \mathrm{am}$ to $10.30 \mathrm{pm}$ and offers a variety of international à la carte dishes and Asian cuisines for dining. Moreover, the hotel has a Pool Bar, Business Center, Courtyard Spa, Fitness Center, Kids Club, Ballroom, and Meeting Room. The result shows that the hotel owns many facilities, thus it raises a critical assumption on how the hotel's ability to undertake CHSE activities.

\section{Process for Obtaining CHSE Certificate}

Courtyard Hotel by Marriott Bali Nusa Dua Resort conducted a series of activities to obtain a CHSE certificate. Information related to these activities was obtained from a direct interview with a management representative, Mr. Dhaniel Fernando as the Training Manager. He explained that although CHSE is a new program implemented in hotels, the training process must follow the procedures. Further, these activities must be equipped with training materials, which will initially be examined and studied by the Human Resources Department, namely the Training Manager. Afterwards, the Training Manager processes the program in the form of training materials and then conducts training to all hotel employees by providing theory and practice. Therefore, all employees can understand efficiently. When the training activity has been passed, all employees will take a Post Test which aims at determining how much employees have progressed over a term of training. Those who have participated in the training program will be input directly into the system. Although CHSE is a new program, all employees, even management must participate since this is a government program.

Other information gained was the participant of the training. The CHSE training conducted by Courtyard Hotel by Marriott Bali Nusa Dua Resort, has been attended by 248 participants, they are active employees/staffs of the hotel. CHSE training program was conducted for three months, from July 2020 to October 2020. To facilitate participants' understanding of the program, the training was divided into two sessions; first session concerns with theoretical presentations online while second session is the simulation or practical training conducted at the hotel. A specific CHSE materials as well as other supporting materials were given by the training manager so that all employees are well prepared. As stated by the training manager, Mr. Dhaniel Fernando:

"Materi yang diberikan dalam pelatihan haruslah sesuai denganprogram pelatihan untuk itu kami tentunya menggunakan panduan yang telah diberikan serta menggabungkan materi Commitment to Clean dari Marriot 
karena materi ini sendiri adalah turunan dari program CHSE'(interview data, on March 28, 2021).

During training process to obtain CHSE certificate, the management has not been able to seek a face-to-face process due to Covid-19 issue in Bali. However, an application through an online media supported by the Microsoft Team was the solution. The use of several video tutorials and live demonstrations from several employees invited to the session were indeed practical. For the record, each department, such as the front office department was given a different achievement depends on the number of direct contacts with potential tourists. Referring to the theoretical training, the activities conducted seem to be in accordance with that theory. Hariandja (2002:186-188) argues that there are two different kind of training methods, namely, on the job training and off the job training. The hotel seemed choosing "off the job training" method, using lectures, video presentations, role playing, learning programs, and simulations. There were some interesting points found from the data that were not mentioned from Hariandja's theory. This was obtained from the interview with Mr. Fernando, as follows:

"Dalam membangkitkan minat karyawan untuk mengikutiprogram pelatihan ini, apa lagi usia para karyawan adalah usia yang sudah terbilang matang dalam industri kerja maka hal yang dilakukan adalah menggunakan personal mode yang dimana saya memberikan pengertian serta membangun dan membuat mood mereka tetap baik dan terus mau belajar serta membungkus materi pelatihan dengan halhal yang menarik seperti memberikan games"(interview data, on March 28, 2021).

The additional elements, namely, games and quizzes, implemented by Courtyard Hotel by Marriott Bali Nusa Dua Resort seems to add the training theory of Hariandja which could be expected as a solution during online training.

After the training process was completed, it did not necessarily get a certificate. The next activity was visitation from the appointed assessor to conduct an assessment/direct visit to the hotel. For information, the Courtyard Hotel by Marriott Bali Nusa Dua Resort must pass this process as a prerequisite to be able to get a CHSE certificate. A certificate was finally issued after a series of CHSE activities completed. Figure 4.1 is a proof that the hotel has passed the CHSE program. 
Figure 4.1 E-Certificate CHSE Hotel Courtyard Nusa Dua

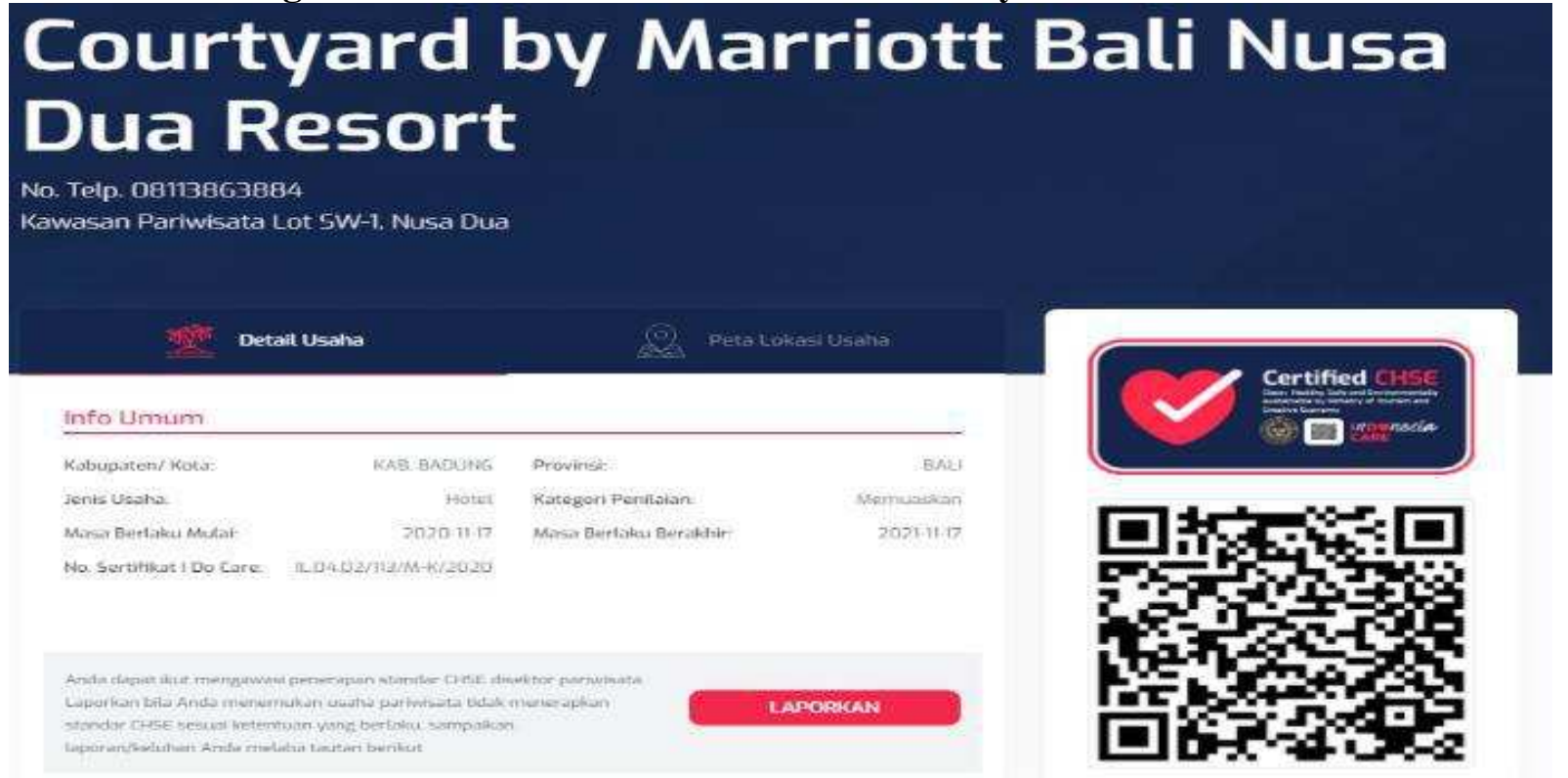

Source: Human Resources Department of Courtyard Hotel by Marriott Bali Nusa Dua Resort

\section{Implementation of CHSE Program at Courtyard Hotel by Marriott Bali Nusa Dua Resort}

In general, the implementation of CHSE program for guests and hotel employees has been running correspondingly. This is supported by the results of the observations for two days. All vital objects that could potentially be the source for the spread of Covid-19 have been carefully observed and documented. The observation also showed several important points. First, temperature checks were carried out for all visitors, guests, and employees before entering the hotel. If it is more than 36.8 degrees Celsius, it is forbidden to enter the hotel area. During the observation, it was found that visitors, employees, and guests must wash their hands in the wash basin provided, then rub the hand sanitizer on their palm. Regarding the use of masks, it appeared that visitors, employees, and guests were discipline in using masks. The seating distance was applied in the restaurant as well as the arrangement of the queue distance was applied in the front office area. From the observation, an appreciation should be given to the management of the Courtyard Hotel by Marriott Bali Nusa Dua Resort who has implemented CHSE protocols in details.

Second, the Courtyard Hotel by Marriott Bali Nusa Dua Resort was trying to educate and took preventive actions related to the spread of Covid-19. A warning (sign) on hygiene and health "by always washing your hands" was seen everywhere. In addition, the hand sanitizers were also provided in several areas such as the front office, restaurant, employee canteen, and several walls leading to the hotel management office. In Figures 4.2 and 4.3, some efforts have been made by the hotel in carrying out the health protocols as well as educating media by attaching signs to public area. Some recommendations on social distancing, how to wash 
hands, and sneezing etiquette were also seen and photographed during observations. This indicated that the hotel has implemented CHSE protocols and attempted to prevent the spread of the Covid-19 pandemic.

\section{Figure 4.2 Recommended Handwashing Techniques and Equipment}

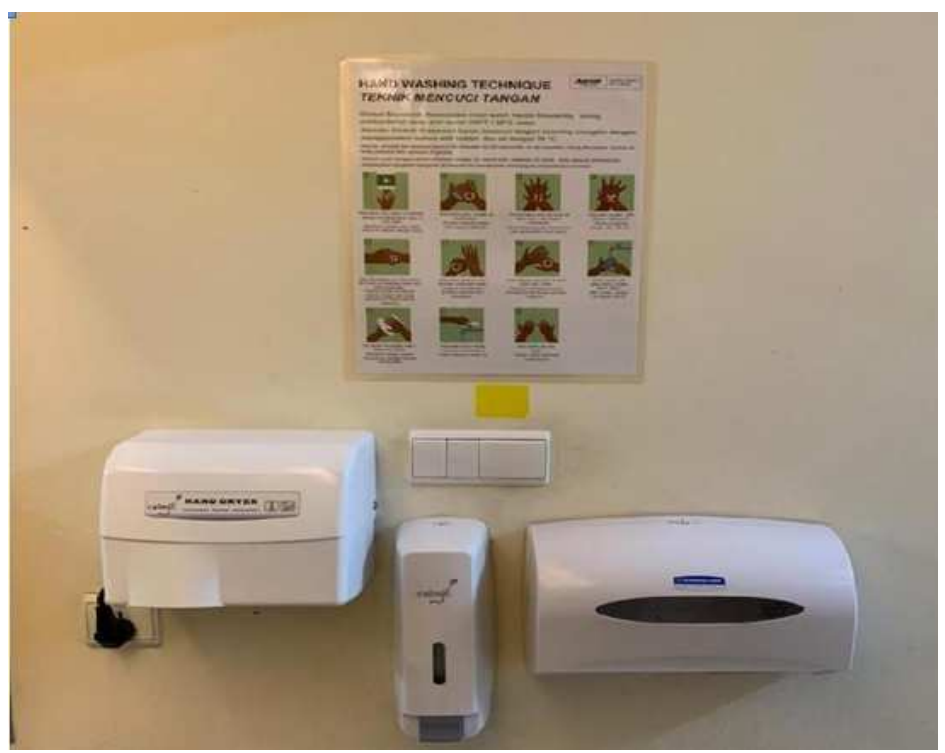

Source: Observation document in Courtyard Hotel by Marriott Bali Nusa Dua Resort

Third, based on the observation at the Courtyard Hotel by Marriott Bali Nusa Dua Resort, several places that were often touched by guests, such as, doorknobs or chairs and tables in the front office area were regularly sprayed with disinfectant. This was in accordance with the standards of CHSE program as an attempt to prevent the transmission of covid. This activity seemed to be in accordance with the recommendations of CHSE program. 
Figure 4.3 Social Distancing Suggestion Board

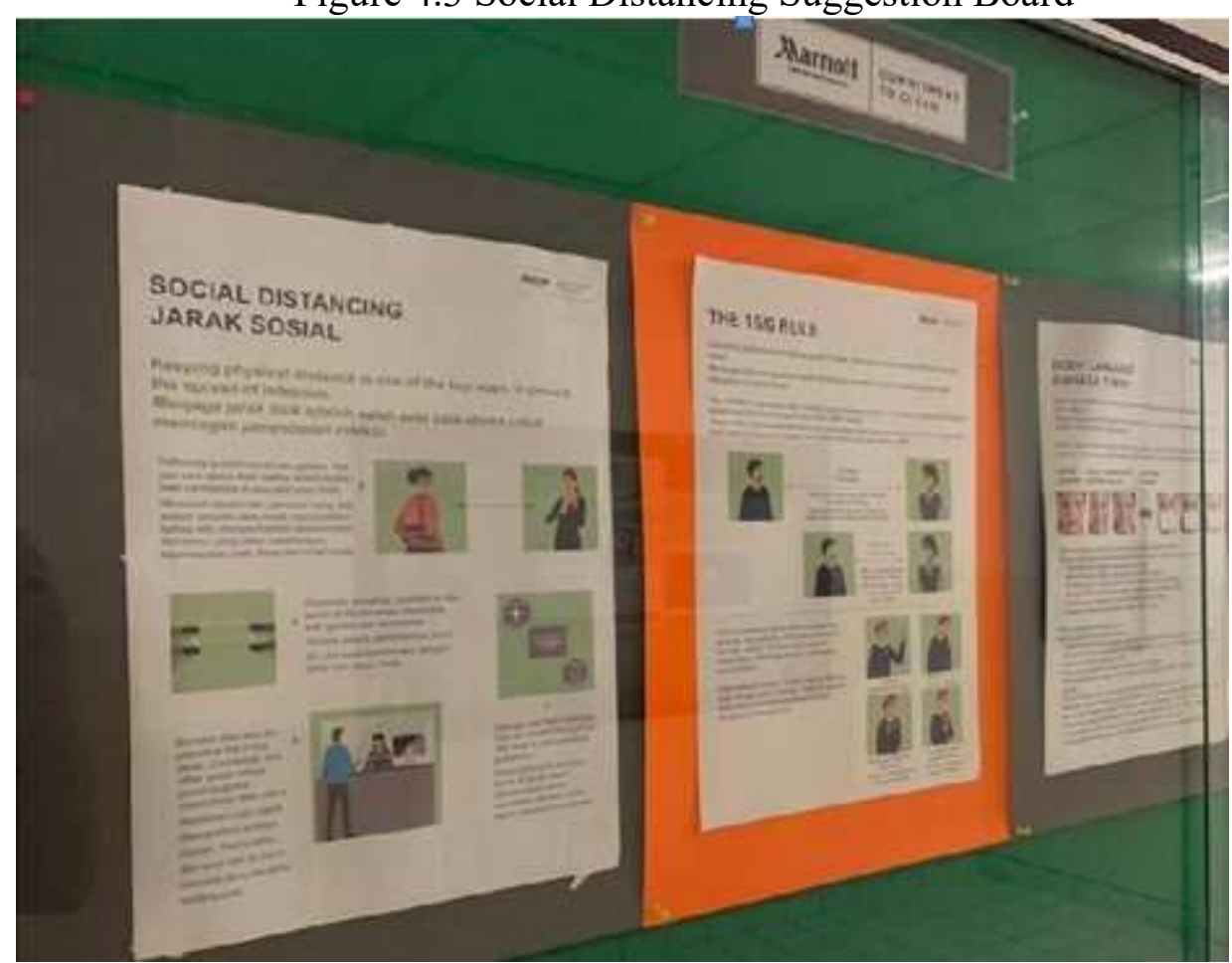

Source: Observation document in Courtyard Hotel by Marriott Bali Nusa Dua Resort

In addition to the three points above, there were several things found from the observation. This was the hotel's compliance with the government's recommendation during pandemic in applying 50 percent of employees who were in charge. This seemed to be in accordance with the condition of the hotel, not only at the Courtyard Hotel by Marriott Bali Nusa Dua Resort, but also at other accommodations in Bali due to the lack of income and decreasing number of tourist visits. Another finding was the waste problem. The pandemic issue and the CHSE's demand of minimizing direct contact and throwing something away as soon as possible, became the hotel's homework for solution. It was demanded that the hotel paid attention to the waste problem.

Behind the appropriateness and the disciplinary efforts practiced by the Courtyard Hotel by Marriott Bali Nusa Dua Resort, there were still several things needed to be addressed and managed. Discipline is needed to be improved in the future because several times hotel employees seemed to take off their masks when communicating with their colleagues. Social distancing needed to be improved, especially during communication among employees. The old habit was still shown several times when employees were together. Speaking loudly, especially if there were guests, could cause inconvenience to the guests. An interview with HRD showed that there was no clear SOP regarding to the rewards and punishments related to CHSE program. The most important thing was the hotel budgeting for CHSE facilities, such as provision of disinfectants and the installment of facilities for temperature checks, and hand gloves.

In theory, what is shown by the Courtyard by Marriott Bali Nusa Dua Resort 
hotel is nothing more than a form of "negotiation". The negotiation is explicitly making peace with the situation and going with the flow. Participating CHSE program is a non-verbal negotiation aimed at the government, as a form of compliant or in other words "hegemony" to the government regulation. Negotiations are also performed as a responsibility requirement to the employees, visitors, and potential guests.

Further discussion of the negotiations is presented as follows. The word 'negotiation' in 'licensing negotiation' comes from the English language "negotiation" which means a discussion aimed at reaching an agreement or a conversation in reaching the word "consensus". Negotiation is a process of combining a dispute in an atmosphere of impartiality or in the same position through diplomacy, rationality, and problem solving (Kissinger, 1969) in Alfrendson (2008: 6). Negotiation according to Daniel Druckman (1997) in Alfrendson (2008: 7) is a stage in the process. However, in practice its implementation is essentially a problem solving, as a bargaining game, as part of a management organization, and diplomacy that has a political signal.

Negotiation practice at Courtyard Hotel by Marriott Bali Nusa Dua Resort by implementing CHSE program, has two significations. The first meaning is that the practice that occurs at the Courtyard Hotel by Marriott Bali Nusa Dua Resort does not want to be left behind or stay updated to keep getting guests either in postCovid-19 pandemic, or later in the era where the Covid-19 becomes endemic. The second meaning, through CHSE, which is a safety standard, although there are many sacrifices such as an extra budget for safety that must be disbursed by the hotel, it looks forward that business is expected to be able to provide assurance (guarantee) of the safety and health of tourists which of course leads to tourist satisfaction and boils down to the hotel's profit.

\section{CONCLUSION}

In general, the implementation of CHSE at the Courtyard Hotel by Marriott Bali Nusa Dua Resort has been succeeding. This can be seen from the implementation of health protocols, such as: temperature checks, wearing masks, washing hands, signs of health and work safety were well attached and positioned. However, several things such as the discipline of employees, visitors, and tourists must be monitored continually and SOP regarding to this issue should be formulated. Meanwhile rewards and punishments should also be effectuated.

\section{REFERENCES}

Barker, Chris. 2005. Cultural Studies: Teori dan Praktik. Terjemahan Tim Kunci Cultural Studies Center. Yogyakarta: Bentang.

Barker, Chris. 2014. Kamus Kajian Budaya. Yogyakarta: PT Kanisius.

Bangun, Wilson. 2012. Manajemen Sumber Daya Manusia, Jakarta: Erlangga 
Batam Tourism Polytechnic. 2020. CHSE: Protokol Kesehatan untuk Pariwisata dan Ekonomi Kreatif. Diakses pada 12 Juni 2021, dari: https://btp.ac.id/protokol-kesehatan-chse/

Dessler, Gary, 2011. Manajemen sumber daya manusia. Jakarta: Penerbit Indeks

Hamalik, Oemar. 2007. Manajemen Pelatihan Ketenagakerjaan: Pendekatan Terpadu. Jakarta: Bumi Aksara

Kasmir. 2016. Manajemen Sumber Daya Manusia (Teori dan Praktik). Depok: PT Rajagrafindo Persada

Kementerian Pariwisata dan Ekonomi Kreatif / Badan Pariwisata dan Ekonomi Kreatif Republik Indonesia. 2021. Cara Mendaftar Sertifikasi CHSE Pariwisata. Diakses pada 12 Juni 2021, dari: https://www.gramedia.com/best-seller/cara-menulis-daftarpustaka/\#4_Cara_menulis_Daftar_pustaka_dari_Internet_atau_Website Kementerian Pariwisata Dan Ekonomi Kreatif/ Badan Pariwisata Dan Ekonomi Kreatif .2020 .Panduan Pelaksanaan Kebersihan, Kesehatan, Keselamatan, dan Kelestarian Lingkungan di Hotel Edisi Juli 2020. Jakarta: Kemenparekraf

Yanwardhana, E. 2021. Dihantam Covid-19, Begini Kondisi Menyedihkan Ekonomi Bali. CNBC Indonesia. https://www.cnbcindonesia.com/news/20210522173134-4247581/dihantam-covid-19-begini-kondisi-menyedihkan-ekonomi-bali 